\title{
India and China in the Indian Ocean: Changing Dimensions of Maritime Strategy
}

\author{
Anju Lis Kurian \\ School of International Relations and Politics \\ Mahatma Gandhi University \\ liskurian@gmail.com \\ C. Vinodan \\ School of International Relations and Politics \\ Mahatma Gandhi University \\ Kerala, India \\ vinodan.c@gmail.com
}

\begin{abstract}
In Asian and global power politics a maritime strategic angle concentrates on the value of fortifying and controlling sea lines of communications (SLOCs) for stability, economic growth, and development of nations. Consequently, both India and China are snooping to control SLOCs and safeguard their emergent and escalating worldwide interests. The advancement in and expansion of naval power satisfies the corresponding nationalist aspirations of Beijing and New Delhi. As a result, the development of their maritime capabilities would have a greater impact on the naval security architecture in the Indian Ocean. The hike in Chinese engagements across the Indian Ocean widely known as the String of Pearl's stratagem is principally stimulated by a policy of maritime encirclement of India. Struggle to secure tactical energy resources which are quickly revolutionizing their navies could induce clashes and have major repercussions for global security affairs. Harmonious handling of both China's and India's cooperation will be crucial for regional as well as international peace and opulence shortly and everyone looks upon a fabulous Asia reflected in the world. Thus, this paper analyses the underlying factors that motivate both countries to have ambitious objectives in the Indian Ocean and could find out that securing energy is one of the driving forces in securing maritime dominance across the Indian Ocean.
\end{abstract}

\begin{abstract}
Keywords: India and China, String of Pearls, Maritime Strategy, Indian Ocean, Energy Security
\end{abstract}

JEL Classification: O10, F5, F59

Article History

Submitted: 24.01.2021

Accepted: 14.12.2021 


\section{Introduction}

The $21^{\text {st }}$ Century is marked with the changeover in the center of geopolitical gravity from the Occident to the Orient where India and China are nemine contradicts considered as the engines of development for the Asian and international political economies (Raman, 2011; Srimal et al., 2018). Moreover, they search for a global power status by recouping the supremacy they have savored just before the initiation of the industrial revolution. For instance, in 1820 India and China together contributed nearly half of the world's income and 60 percent of the global GDP came from the Asian continent. In the present global system, China and India represent diverse cultures and competing models of development. However, in international relations, the magnitude of their relationship lies in the fact that China and India add up to nearly two-fifths of humanity and their huge markets play a deceive role in world markets. So, their underlying strategic disagreement and rivalry over issues extending from land as well as water to geopolitical influence draw ever more international attention. In this milieu, the connection between the two promising economies divulges ground-breaking ramifications for global security and Asian overall influence elements (Chellaney, 2012).

For more than a decade both the countries enjoyed mostly an incessant improvement in their political, economic, and security cooperation though there are unsettled boundary clashes, mutual qualms over military expansion and strategic objectives, potential economic race, and the drifting power balances and rearrangements (Yuan, 2007). Earlier for Beijing, India was a peer competitor due to its hindering problems such as poverty, poor infrastructure, and sluggish bureaucracy. But in recent times China is rendering mounting attention to New Delhi because of its strive for great-power status through diplomatic inventiveness and military build-up. Chinese concern over New Delhi is mainly focussed on four strategic advancements: 1) India's evermore articulated regional and international assertiveness, 2) its conspicuous defense modernization, 3) a potential U.S- India nexus and 4) an innovative regional and multilateral initiatives (Yuan, 2007). In Asian and global power politics controlling sea lines of communications (SLOCs) are crucial to the stability, economic development, and growth of nations. At the same time, a maritime strategic dimension concentrates on the value of safeguarding sea lines of communication and crucial chokepoints of conjoining water bodies (Brewster, 2011). Consequently, both countries are snooping to control SLOCs and safeguard their emergent and escalating worldwide interests. In addition, it is quite natural that great powers always aim for a vaunting navy which is considered as a matter of cachet. The modernization and expansion of navies are multidimensional usually with economic, social, and diplomatic reasons. The advancement in and expansion of maritime power executes the corresponding nationalist aspirations of Beijing and New Delhi. As a result, the development of their maritime capabilities would have a greater impact on the maritime security in the Indian Ocean which is one of the most significant regions of the world from ancient times onwards (Basit and Oystein, 2012).

\section{Materials and methods}

The paper has followed the historical analytical method for analyzing the maritime strategies of India and China for dominance in the Indian Ocean. Here, the four common modes of writing in historical research such as description, narration, exposition, and argument have been used to compare the maritime strategies of India and China in the Indian Ocean. The data on various dimensions of maritime strategies of India and China have been collected from various sources such as government reports, articles, books, and web resources.

\section{Results and Discussion}

Traditionally Chinese rulers emphasize territorial power over maritime power. Nevertheless, China was the largest naval power at the beginning of the fifteenth century during the Ming dynasty though that has ended with the ingress of the Portuguese into the high seas. Modern China has witnessed successful economic reforms since the 1980s which enhanced its clout and switched the country's strategic ambitions from time immemorial to craft its existence to the current targets of safeguarding steady financial growth. The change demarcates an essential shift for China, changing from a closed country to a developing one that has irretrievably incorporated it into the globalized world (Tsai, 2015). In the mid-1980s Beijing began to reorient its military strategy from the mainland and coastal defense to an outward power jutting capacity by sea power modernization to build a blue-water navy. Naval force modernization programs have included 
technological updates across the fleet, acquiring the latest superior weapons, expanding a rigorous strategic dogma i.e., offshore defense, and ameliorating the excellence of personnel via training. The reinvigorated naval doctrine intends to become a global maritime force to handle not only with tactical concerns to the east but also to contest with the U.S intervention in their sphere of influence and beyond (Walgreen, 2006).

At the turn of the twenty-first century, Chinese naval modernization assumed a renewed face with the advancement of submarine force and the intensified nuclear acquisition program. The major driving force behind the near-seas active defense strategy is the Taiwan dispute which is a major point of discussion along with defending maritime sovereignty privileges, policing SLOCs in the adjacent seas, maintaining strategic nuclear deterrence, and proclaiming China's eminence as a major global power. The Dragon wishes to believe that their far-seas operations are based on the objective of forming a concrete basis for adjudicating the Taiwan issue as well as maritime boundary clashes. Moreover, the new naval orientation became a necessity for China to safeguard its oil supplies as well as marine trade itineraries. Again, China's economic advancement, its amalgamation with the global economy plus fruitful resolution of most of its border altercates have also enabled China to explicate a wider strategic outlook and pay much care in protecting the SLOCs used for its key maritime activities (Basit and Oystein, 2012). Chinese naval force modernization has a far-reaching ramification for India because China's naval competence exceeded India's by both quantitative and qualitative strings. Yet, their capability to exhibit pre-eminence over the Indian Ocean is critically restricted by the distance from ports in southern China as well as its absence of logistical support in the Indian Ocean thus it depends on chokepoints chiefly the Strait of Malacca to deploy to the Indian Ocean (Ramadhani, 2015). Here the strategy of the string of pearls obtains importance both for China and India. China's strategic ventures engulfing India are intensifying the geopolitical competition by the Chinese construction of new ports in Sri Lanka and Pakistan, new transportation links with Myanmar, Nepal, and Pakistan, and China's advancements to military infrastructure in Tibet. The foremost obvious goal of China through their assertive naval strategy is to overcome India's maritime predominance in the Indian Ocean a theatre crucial to fashioning China's superiority in Asia just like any powerful nation across the world. Another Chinese strategy against India is to strengthen its ties with Pakistan to retain India under blackjack (Chellaney, 2012). On the other hand, Indian strategic thinking has attained partial reorientation from a purely continental towards a more maritime perspective that will enable India to become a supreme naval power in the Indian Ocean (Brewster, 2011).

Compared to China, India is a laggard in the initiation of the program to enlarge the blue water navy including considerable hikes in naval expenditure. Since the mid-1990s capital expenditure on the upgradation of naval force has increased which invigorated plans for noteworthy modifications in the Indian Navy's force architecture with special vehemence on maritime control capacities. With the ascendency of Chinese strategic ambitions in the Indian Ocean region, India has been actively involved in formulating security alliances that are envisioned to augment India's potential to portray the power and confine China's potential to widen security alliances (Ayres, 2017). Due to the idiosyncrasy of the Indian Ocean as an encased ocean, the Indian Navy has given conscientious concentration to the gag focuses at passageways to the Ocean around southern Africa containing the Mozambique Channel, the Arabian peninsula constituting the Strait of Hormuz and Bab-el-Mandeb, and the straits interfacing the Indian as well as the Pacific Ocean through the Indonesian archipelago including the Malacca, Sunda and Lombok straits (Brewster, 2010).

India explicitly pronounced its maritime strategy in 2007 in the document titled 'Freedom to Use the Seas: India's Maritime Military Strategy'. This study has discussed three important navigators behind India's strategies for its navy: first, India's reliance on safe sea lines of communications (SLOCs), particularly for oil as well as gas imports and other commodities. This endeavor to combat piracy plus rescue missions after natural disasters and responding to various non-traditional maritime risks like terrorist attacks using sea routes; secondly, the risk of military conflict due to the uncertainty regarding the intentions of other actors in expanding their maritime power in the region; and finally, the imperative of national pride that means India considered the Indian Ocean as its traditional area of influence and currently the country pursuit for a more emphatic performance in the Ocean in connection with its mounting ambitions for dominant power. All these naval strategies are interrelated in many ways and are well portrayed in India's official maritime documents (Basit and Oystein, 2012). 
India's current maritime programs, as well as projects, are said to be intended in formulating a steel ring surrounding its territories as a response to China's string of pearls strategy in the Indian Ocean. There are many reasons for the accused policy such as the Indian navy has a surveillance post in Madagascar, cordial naval ties with Maldives, naval bases in its territories in the Andaman and Nicobar Islands in the Bay of Bengal and on the Agalega Islands of Mauritius, a port project in Chabahar in southern Iran, and collaboration with an array of nations like Oman, Mozambique as well as South Africa on the African continent's east and south coast, and several South-East plus East Asian states, comprising Japan and Vietnam. The underlying reason for India's renewed emphasis on naval modernization is the perceived challenge from China. The reports on Chinese plans to develop communication as well as helipad amenities on Myanmar's Coco Islands of India's east coast as part of what India conceives Beijing's vision of surrounding its territory is a threat to India. As a response, India is attempting to counterpoise China's increasing interferences with its whereabouts in the coastal nations where it has commendable tralatitious benefits. Also, India carefully watches China's engagements in the Ocean as its undertakings may probably challenge India's security interests (Basit and Oystein, 2012). In recent years India has initiated an important naval build-up by acquiring vital naval platforms from Russia and its navy currently grades seventh globally in size plus the sole nation in South Asia as well as one of the nine in the world to acquire an aircraft carrier (Yuan, 2007).

\section{The Indian Ocean and the String of Pearls}

The Indian Ocean is the world's third-biggest maritime bowl which represents $20 \%$ of the world's water surface encompassed by 56 nations. The littoral countries have tremendous mineral assets involving oil as well as natural gas and some are among the world's quickest developing buyer markets (Basit and Oystein, 2012). By resting in the middle between the incredible economies of the Indian subcontinent and the Far East and inside the oil-rich Gulf territory, the Indian Ocean assumes a pivotal position. Historically, the Indian Ocean has been home to a portion of the world's most crucial sea lines of communication for worldwide exchange and its significance has risen again by getting one of the busiest ocean paths on the planet for commodity trade, capital, manufactures and services. The SLOCs in the Ocean account for almost half of the global container traffic plus approximately 70 percent of petroleum goods traffic (Farooq, 2007). Alfred Thayer Mahan was an American sea power theorist, the Chinese analysts are fond of referring to him to accentuate the strategic significance of the Indian Ocean. The most famous quote credited to Mahan is also the most overwhelming in its sweep: 'Whoever controls the Indian Ocean dominates Asia. This ocean is the key to the Seven Seas. In the $21^{\text {st }}$ century, the destiny of the world will be decided on its waters' (Yoshihara, 2012; EFSAS, 2019).'

Maritime competition with China has reoriented India's strategic perspective and strengthened its concentration in achieving naval dominance across the region (Ganguly, 2015). India's reputation as the most crowded country in the Indian Ocean realm and its fundamental gesture in the northern Indian Ocean has long contributed to the beliefs in New Delhi about India's vocation to control the eponymous sea. The recent reports feature the common grounded custom among the Indian think tanks that the Indian Ocean is or should be India's Ocean (Brewster, 2011). Indeed, even before India's freedom, India's most popular maritime strategist K.M. Panikkar contended that the Indian Ocean should remain 'really Indian' pushing the production of a 'steel ring' around India through the establishment of naval bases in Singapore, Mauritius, Yemen, and Sri Lanka. Not only that the significance of the Indian Ocean for India can be seen in the writings of various scholars, some of the famous quotes are the following: "The future of India has been determined not on the land frontiers, but on the oceanic expanse which washes the three sides of India', 'Whoever controls the Indian Ocean has India at his mercy, 'India's security lies on the Indian Ocean, India's future, therefore, is closely bound up with the scan is a can elope gradually as a naval power', and 'India's future greatness lies on the sea' (Yoshihara, 2012).

But in contrast to India's strategic desires in the Indian Ocean, China is developing political as well as business stakes together with its de facto coalition through Pakistan and virtuous political plus economic tieups with Burma, Nepal, Bangladesh, and Sri Lanka. India's troubled relations with South Asian nations even though it follows the 'neighborhood first policy' bolster China's manifestation across the expanse. In addition, China has made substantial investments in these nations thereby trapping the vast markets for Chinese goods and opening opportunities for constructing military-related amenities (Menon, 2017). In the 
view of several Indian strategists, China's activities in Southern Asia such as its integration of Tibet, its alignment with Pakistan, and its cooperation with Burma, Bangladesh, and Nepal are part of an adhesive as well as the efficacious policy of 'encirclement' or 'containment' of India. The enlargement of China's interactions and motivations widely known as the String of Pearls strategy is principally stimulated by a policy of maritime encirclement of India $(\mathrm{Li}, 2013)$. More precisely, a string of pearls is a strategy that envisions crafting strategic dealings with countries from the Middle East to the South China Sea to safeguard China's energy pursuits and other security intentions (Conrad, 2012).

The axiom 'String of Pearls' was first used to portray China's arising maritime interests in a report named 'Energy Futures in Asia' by a safeguard defense contractor, Booz-Allen-Hamilton. The U.S. Division of Defence's Office of Net Assessment has dispatched this report in 2005. Accordingly, the American coinage of the term 'String of Pearls' strategy is utilized concerning how China purportedly is attempting to establish military bases across the Indian Ocean for safeguarding its energy supplies and counter the U.S navy's and the Indian navy's challenges (Basit and Oystein, 2012). Chinese 'string of pearls' Policy includes the security of Chinese SLOCs spreading from China to Sudan. Most of the SLOCs permeating constrictions like Bab El Mandeb, Malacca, Hormuz, and Lombok Strait are numerous geopolitical marine amenities in South Asia. In another way String of Pearls enunciates Chinese rising strategic sway using its fortitude to spate its technique in anchorages and airstrips pooled with geo-political conglomeration to endeavor for having a symphonic ocean (Malik, 2013). However, the thought of String of Pearls quickly picked up an emanation of authenticity in India with fears about China's encirclement.

China's longing to extend power in the Indian Ocean and guarantee the security of its SLOCs has purportedly determined to craft String of Pearls system by establishing a nexus of maritime bases like Kra Isthmus in Thailand, Coco islands in the Andaman Sea as well as Sittwe in Myanmar, Chittagong in Bangladesh, Hambantota in Sri Lanka, Marao in the Maldives, and Gwadar in Pakistan in which Coco islands and Gwadar have Chinese signals intelligence facilities (Kumar, 2011). Likewise, Bangladesh has offered naval access to China in its prized Chittagong port. This was a setback to New Delhi because it has long been sought but to no avail. The access to Chittagong port will facilitate India for its planned natural gas imports from Myanmar for shipment to its northeast region (Hong, 2007). On the one hand, some analysts have pointed out that China's string of pearls strategy will girdle India. On the other, some are suspecting about the actual presence of Chinese military bases in the Indian Ocean (Basit and Oystein, 2012).

Many of the assessments from Indian strategists and defense organizations explicitly declare that China's string of pearls strategy intends to dictate over the Indian Ocean. One of the most outspoken sources discussing China's string of pearls, the Asia Times newspaper has expressed the view that the Indian defense establishment unabashedly perceives the clout of China as the most corking threat to India's safety that continues to bump up and the echoes of this supremacy are mainly sea-based. Again, in an article of 2006, the Asia Times listed out almost all the proposals of China operational or budding in the Indian Ocean and amalgamating together into a plan of China's aspirations to militarily dominate India in the Indian Ocean. The newspaper has the opinion that Gwadar port has a far-reaching implication in China's outline. It is considered as the western-most pearl in China's string of pearls strategy, the other pearls being naval amenities in Bangladesh, Myanmar, Thailand, Cambodia, and the South China Sea (Conrad, 2012). Every pearl is seen as a demonstration of Chinese geopolitical sway and its desire to ascertain its presence in the Indian Ocean Region.

As everyone believes, in all the pearls in the strategy the Gwadar port in Pakistan deserves exceptional deliberation. The joint Pakistan-China enlargement of Pakistan's strategic naval base at Gwadar on the Makran coast has extensive strategic implications for two reasons. First, it opened up China's direct access plus basing facilities in the Indian Ocean, and second, it provides propinquity to the Straits of Hormuz (Farooq, 2007). The Gwadar port was conceived at the beginning of 2001 and the U.S. invasion of Afghanistan gave an impetus to it which operationalized in 2007 ahead of schedule. The Gwadar with twelve berths and terminals with the capability to cater ships in the 200,000-ton class together with a large special economic zone forms it as one of the biggest as well as most tactically positioned deep-sea ports in the globe. For China, the port is strategically very important due to copious reasons, some are the following: 1) the project is gestated as a means to weaken India's capability to cordon Pakistan at a time of war, 2) it will enhance the ability of China to supply Pakistan, 3) the port enables Pakistan to be a corridor for trade 
as well as a conveyance from the Central Asian Republics (CAR) to the rest of the Earth, 4) Gwadar facilitates China's maritime trade passing to the Persian Gulf, 5) the port also delivers an energy route to overcome China's vulnerabilities in the waters of the Indian Ocean, 6) it will endow with opportunities of economic growth in the western parts of China, and 7) for the Chinese navy, Gwadar offers a new entry to the Indian Ocean and can be utilized during a military contingency. Based on some reports, it is vital to note that the port has been deepened from 11 to 14 meters as deep as 19 meters. According to the analysts, a port as deep as 19 meters is only beneficial for carriers and nuclear submarines which raises doubts about the genuine intentions of China through these initiatives in the region (Kumar, 2011).

Several hawks have the opinion that China's putative encirclement strategy can be justified on the grounds of India's more offensive approach which advocated a policy of 'counter-encirclement' of China via involving in security partnerships along China's fringes in Southeast Asia, Northeast Asia, and North as well as Central Asia. India's establishment of security amenities in Tajikistan and Mongolia is taken as a sign of India's counter-encirclement strategy in China's Central Asia and North Asia and on the eastern periphery, such a strategy might be navigating India's relationships with Vietnam, Taiwan, South Korea, and Japan. Also, a counter-encirclement strategy is employed for the tangible Indian security existence on China's periphery like Indian management of the Malacca Strait, an Indian naval presence in the South China Sea, and even in the Sea of Japan (Brewster, 2011). According to Chinese analysts through these efforts, India is in quest of further consolidating its South Asian dominance and control of the Indian Ocean and building up to minimum but credible deterrence against China. Hence India has emerged as an indisputable predominant power in South Asia at the end of the Cold War and was unsurpassed in the region by every indicator from military strength to economic power. It is currently aspiring for global great power status i.e., evident in its pursuit for a permanent seat in the UN Security Council (Yuan, 2007). Despite these existing realities, New Delhi is looking at the String of Pearl's theory as an unhealthy and compulsive preoccupation of China in their sphere of influence. Besides the Indian security community is not as confident as to believe China's engagements in the region as a legitimate reflection of their commercial interests or strategic interests in protecting the SLOCs around the Indian Ocean. Even those who acknowledge China's interests in SLOC's security argue that China is overstepping the limits to the extent of establishing a sway over the Indian Ocean region thereby generating a security dilemma for India (Brewster, 2010).

Whatsoever is going on in the power realm of the Indian Ocean region, many Chinese admit that India will dynamically retort to Beijing's ingress into New Delhi's nautical neighborhood. The Indian Maritime Doctrine of 2004 abrasively proclaims that China is trying to 'strategically encircle India' that indicates India's predispositions towards the existence of extra-regional powers in its maritime vicinity. India's hegemonic approach to its adjacent waters operates strongly which obliges great powers to sustain a balance in the international system. India's interactions in the expanse from time immemorial, its favorable geographic location, and its strategic traditions have together fostered a persisting resentment and revulsion towards extraneous interests in the Indian Ocean and its littorals. But China, a nation skyrocketing to great power status looks upon the waters to its southwest as the only strategically significant space within which it could channelize and materialize its rising power dynamics (Yoshihara, 2012).

\section{The Dimension of Energy Security}

Today, energy security unquestionably landscapes both China's and India's diplomatic as well as strategic calculations. Chinese leadership often voiced concern about energy security and the question of reliable plus safe imports of oil is always in its national security interests. In late 2003 President Hu Jintao voiced alarms about the security of energy imports to China since about 80 percent of China's oil imports are shipped through the Strait of Malacca. Later in 2005, at the time of leading the State Energy Leading Group, Premier Wen claimed that 'energy is an important strategic issue regarding China's economic growth, social stability, and national security.' Again in 2006 during the G8 summit, President Hu stressed the issue by declaring that 'global energy security has a bearing on the economic lifelines and the people's livelihood of various countries and is of utmost importance to maintaining world peace and stability and promoting common development of various countries (Basit and Oystein, 2012).' 
The Sea Lines of Communications (SLOCs) proceeds from Asiatic Monsoon Rimland to Suez is a foremost energy vexation for China. So, China is following a strategy of maintaining its SLOCs secure by following the String of Pearls for its energy securities in the U.S eclipsed Indian and Pacific Oceans. The latest IndoU. S plans to work in coaction to control the Indian Ocean recognizes the legitimacy of all littoral countries to protect their strategic pursuits (Malik, 2013). The Indian strategists and naval researchers underlined the connections between India's leapfrogging as a maritime power as well as its energy security requirements. They emphasized the fact that without safe SLOCs India's economic development is in peril. Therefore, the race to acquire strategic energy assets in Asia which are quickly overhauling their navies could induce clashes and have commendable entailments for global security and affairs among the great powers in Asia and beyond (Basit and Oystein, 2012).

The brisk expansion of the Chinese economy has resulted in an enormous augment in China's energy requisites. Among these energy demands, petroleum products rank in a primary position. In 1993 China was a net oil importer and contributed to 40 percent of the world's oil growth. But by 2003 it became the second biggest user of oil (Malik, 2013). China's emphasis on unrelenting economic growth is the vital focal point of its grand strategy enforces them to either assertively or aggressively ascertain dealings with energyproducing and distributing countries. Then, China is endeavoring to devise strong ties throughout the Indian Ocean particularly with states in Central and Southwest Asia including the Middle East. The management of the supplies and transport required for the supply of energy means that China must build up secure lines of transport across the expanse both on land and mainly through waters. The swiftness in China's amplified enthusiasm for energy supplies is amazing, excogitating the state's swift monetary gains and the current growth rate places the country's eternal oil dependency at 30-35 percent and growing day by day. So, China is striving to access energy resources in all corners, not only in the East and South China Seas but also in Central and Southwest Asia. It is not surprising that the current expansion of China's financial bonds across the region as well as its endeavor to enhance logistical abilities by considering the fact of the Indian Ocean region holds the lion part of global energy production (Walgreen, 2006).

Late in the Cold War China has turned into a market-based economy that forced it to steadily widen its relations throughout the region. China has signed numerous oil field development contracts with Iran and 15 percent of Chinese oil needs are met through import from Sudan. The alarming billow of piracy in the propinquity of the Horn of Africa and vulnerable situations in many of the African and Middle Eastern countries has formed a bugged Chinese policy to handle such aggressions. Just like all other nations in the world, China also has the legitimacy to defend its national stakes by protecting its SLOCs in the Indian Ocean from where 70 percent of its energy flows. China's alliances with nations in and around the Indian Ocean or the execution of China's string of pearls strategy consolidated via arms sales and political, economic, and diplomatic backing (Hu, 2017). However, some writers suggest that these efforts will not counteract the SLOC defense challenge or insulate China from energy-linked vulnerabilities. But Beijing hopes the string of pearls can provide it maximum security. For example, Kra Isthmus could render a secure as well as a substitute path instead of longer, vulnerable and the U.S dominated three km narrow chokepoint at Malacca in between Hambantota to Shanghai. Because the only power capable of gravely interrupting oil supply to China in the US, which is the country primarily dominates the Indian and Pacific Oceans maritime activities (Malik, 2013; Basit and Oystein, 2012).

China has compounded its economic tie-ups through the direct investments and skillful deployment of economic inducements to draw Bangladesh, Nepal, Pakistan, and Sri Lanka into its strategic ambit. From the energy perspective, the cooperation with Bangladesh is very significant because of its vast natural gas assets specifically 60 trillion cubic feet. China's energy game reflects the establishment of the Shanghai Cooperation Organization (SCO) in 2002 and the forging of new mutual energy accords with all the Muslim states from east to west i.e. Kyrgyzstan to Iran. Its bilateral ties acquired a strategic dimension particularly after the US military operations in Afghanistan in 2001. Now its operations in the region are targeted not only to enhance China's access to energy supplies but also to equipoise the U.S. involvements in the expanse (Walgreen, 2006).

The existing discord between India and China in the energy sector also reflects its competition over the dominance of the Indian Ocean. India and China are reliant on similar energy sources and contest each other to acquire hydrocarbon assets for their amplifying economy in all possible channels. In their recent 
struggle for energy resources, China has trodden India in the tight race for oil assets in Kazakhstan, Ecuador, and Nigeria through both assured for future collaboration in quest of energy supplies. According to Sumit Ganguly, India has competitive and not conflictual engagements with China in their joint quest for energy resources. China's motives to avail its reach to overseas energy resources have brought it into India's backyard because energy resources from East Africa and the Persian Gulf must cross the Indian Ocean to make their way to the market in China. In an endeavor to safeguard its intentions, China has succeeded in establishing a web of ports and alliances with nations in the littoral region including states that have traditionally been hostile to India. From the viewpoint of Indian observers, this so-called string of pearls strategy intends to acquire easy reach to places that can be used to project Chinese power in the Indian Ocean. Whatever the intentions and strategies followed by China in the region, the reality is that the country is very active in the Indian Ocean waters and littorals to carry on its wider ambitions (Ladwig, 2009).

\section{Conclusion}

Over the last few years, China and India have taken momentous steps to be major thespians in Asia as well as in the global scenario in both strategic and economic terms. In the Asian context, Beijing has extended its business with numerous states in the region which endow with a double gain of ensuring energy supplies while at the same time framing regional security architecture in favor of China. On the other hand, India's strategic stance is ever more directed towards a maritime dimension along with its ambitions to emerge as the decisive factor in the Indian Ocean. The larger Asian balance of power is fashioned by events not only in the landmass of Asia but also in the waters of the Indian Ocean because of its reincarnation as a new global center of trade as well as geopolitics and energy flows. So, the non-traditional security dilemmas in the expanse like energy security and climate security to transnational terrorism and environmental degradation have evolved as significant as traditional security issues such as freedom of navigation, security of sea lanes, maritime security, the proliferation of weapons of mass destruction, and ocean piracy.

For China, the string of pearls strategy has opened new avenues for its emergence as the major power against India's enduring great power ambitions which append affectional vigor to its thirst for domination over the Indian Ocean. It paved way for pouring additional fuel for mutual distrusts between the two Asian giants. In Indian scrutiny, if China can gain ascendancy in the Indian Ocean at India's expense, it will be a death knell to its world power strides. The great power ambitions of both countries are dependent on each other and an unwavering, reciprocally beneficial equation between them is more likely to be realized. In most of the ongoing transactions, India and China are in a race for regional supremacy. So, now it's the time to seriously examine the way they positively recognize each other thereby restructuring their foreign policies accordingly, and, in this process, both have to relinquish some short-term gains for long-term mutual benefits. The substance and consolidation of the mutual collaboration are crucial as the world's most populous and fastest-growing nations manage their strive towards great power status because in the $21^{\text {st }}$ century the world becomes increasingly affected by the rise of these two Asian powers' phenomenal economic emergence and political sway. Therefore, harmonious handling of both China's and India's cooperation will be vital for regional as well as global peace and opulence shortly and everyone looks upon a fabulous Asia reflected in the world.

\section{References}

Ayres, A. (2017). Will India Start Acting like a Global Power: New Delhi's New Role. Foreign Affairs, 96(6):83-92.

Basit, S. and Oystein T. (2012). Emerging naval powers in Asia: China's and India's quest for sea power, Oslo Files on Defence and Security, Norwegian Institute for Defence Studies.

Brewster, D. (2010) An Indian Sphere of Influence in the Indian Ocean, Security Challenges, 6(3): 01-20.

Brewster, D. (2011). Indian Strategic Thinking about East Asia. Journal of Strategic Studies, 34(6):825-852.

Chellaney, B. (2012). Rising Powers, Rising Tensions: The Troubled China-India Relationship. SAIS Review of International Affairs, 32(02):99-108. 
Conrad, M.E. (2012). Does China Need A "String of Pearls" (Master's Thesis)? Naval Postgraduate School Monterey, California.

EFSAS. (2019). China's 'String of Pearls' exbibits: The Dragon's Great Game of Loans and Debts. European Foundation for South Asian Studies (EFSAS), Amsterdam.

Farooq, S. (2007). Sino-American Relations in the Post-Cold War Era: Implications for South Asia. China: An International Journal, 05(01):78-94.

Ganguly, R. (2015). India's Military: Evolution, Modernization, and Transformation. India Quarterly, 07(03):187-205.

Hong, Z. (2007). India and China: Rivals or Partners in Southeast Asia? Contemporary Southeast Asia, 29(01):121-142.

Hu, R.W. (2017). China's 'One Belt One Road' Strategy: Opportunity or Challenge for India. Cbina Report, 53(02):107-124.

Kumar, P. (2011). The Prospects for Sino-India Relations 2020 (Master's Thesis). Naval Postgraduate School Monterey, California.

Ladwig, W.C. (2009). Delhi's Pacific Ambition: Naval Power, "Look East," and India's Emerging Influence in the Asia-Pacific. Asian Security, 05(02):87-113.

Li, L. (2013). Stability in Southern Asia, In Ashley J.T. and Sean M. (Eds.), Crux of Asia: China, India, and the Emerging Global Order, Washington: Carnegie Endowment for International Peace.

Malik, H.Y. (2013). Beginning of an end in the Indian Ocean. IOSR Journal of Humanities and Social Science, 14(03):100-111.

Menon, S. (2017). Some Thoughts on India, China, and Asia-Pacific Regional Security. China Report, 53(02):188-213.

Ramadhani, E. (2015). China in the Indian Ocean Region: The Confined 'Far-Seas Operations. India Quarterly, 07(02):146-159.

Raman, G.V. (2011). India in China's Foreign Policy. China: An International Journal, 09(02):342-352.

Srimal, F., Megha, G. and Sharon, J. (2018). The Indian Ocean and its Role in Strengthening India's Security, (Framework Document). Retrieved from http://www.ieee.es/en/Galerias/ fichero/docs_marco/2018/DIEEEM17- 2018_OceanoIndico_India_Shrimal-MeghaSharo_ENGLISH.pdf

Tsai, T. (2015). China and India: Comparisons of Naval Competition and Future Strategies. In: Naidu G.V.C., Chen, M. and Narayanan, R. (Eds.), India and China in the Emerging Dynamics of East Asia, India: Springer.

Walgreen, D. (2006). China in the Indian Ocean Region: Lessons in PRC Grand Strategy. Comparative Strategy, 25(01):55-73.

Yoshihara, T. (2012). Chinese Views of India in the Indian Ocean: A Geopolitical Perspective. Strategic Analysis, 36(03):489-500.

Yuan, J. (2007). The Dragon and the Elephant: Chinese Indian Relations in the $21^{\text {st }}$ Century. The Washington Quarterly, 30(03):131-144. 